\title{
Blood cell attachment to root surfaces treated with EDTA gel
}

\section{Adesão de células sangüíneas a superfícies radiculares tratadas com gel de EDTA}

\author{
Fábio Renato Manzolli Leite* \\ Camila Sala Moreira** \\ Letícia Helena Theodoro*** \\ José Eduardo Cezar Sampaio****
}

\begin{abstract}
Root debridement generates a smear layer which contains microorganisms and toxins that could interfere in periodontal healing. For this reason, different substances have been used to remove it and to expose collagen fibers at the tooth surface. Blood element adhesion to demineralized roots and clot stabilization by collagen fibers are extremely important for the success of periodontal surgery. The aim of this study was to evaluate the different patterns of blood element adsorption and adhesion to root surfaces only irrigated with distilled water and after application of a manipulated or an industrialized EDTA gel. Thirty samples were planed, equally divided into three groups and treated with distilled water (control), a manipulated EDTA gel or an industrialized one. Immediately after, samples were exposed to fresh blood and prepared for scanning electron microscopy. Untreated planed dentin presented the best results with blood cells entrapped in a thick web of fibrin. In the manipulated EDTA group, the web of fibrin was thick with sparse blood elements. The worst result was seen with the industrialized EDTA group, in which no blood elements could be seen. Statistical difference was obtained between control and industrialized EDTA groups. Surfaces only irrigated presented the most organized fibrin network and cell entrapment.
\end{abstract}

DESCRIPTORS: Dental scaling; Periodontics; Blood; Fibrin; Smear layer.

\begin{abstract}
RESUMO: A raspagem gera "smear layer", a qual contém microrganismos e toxinas que podem interferir no reparo periodontal. Por esse motivo, diferentes substâncias têm sido empregadas para remover esta camada e expor fibras colágenas da superfície dental. A adesão de elementos sangüíneos a superfícies radiculares desmineralizadas e a estabilização do colágeno pelas fibras colágenas são de extrema importância no sucesso da cirurgia periodontal. O objetivo deste estudo foi avaliar os diferentes padrões de adsorção e adesão de elementos sangüineos a superficies radiculares apenas irrigadas com água destilada e após aplicação de um gel de EDTA manipulado ou um industrializado. Trinta amostras foram raspadas, eqüitativamente divididas em 3 grupos e tratadas com água destilada (controle), um gel de EDTA manipulado ou um industrializado. Imediatamente foram expostas a sangue fresco e preparadas para microscopia eletrônica de varredura. As superfícies dentinárias apenas raspadas apresentaram os melhores resultados, com moderada quantidade de células sangüineas entremeadas em uma fina rede de fibrina. No grupo de EDTA manipulado, a rede de fibrina foi pouco visivel com escassas células. Os piores resultados foram observados com o EDTA industrializado, caracterizados pela ausência de elementos sangüineos. Estatisticamente houve diferença apenas entre os grupos controle e EDTA industrializado. As superficies apenas irrigadas apresentaram rede de fibrina mais bem organizada com células entremeadas.
\end{abstract}

DESCRITORES: Raspagem dentária; Periodontia; Sangue; Fibrina; Camada de esfregaço.

\section{INTRODUCTION}

Mechanical debridement and planing of teeth generate a smear layer, which is formed by calculi, plaque and microorganism cytotoxic residues ${ }^{9,10,14}$. The use of an agent to remove this layer and to expose collagen fibers is an essential factor to obtain biologically acceptable tooth surfaces, which are necessary for the improvement of regenerative procedure success ${ }^{6}$.

The interaction among factors such as root surface contamination degree, plasma and connective tissue is necessary for a new connective tissue formation as opposed to a long junctional epithelium. Sometimes, after wound maturation, a

\footnotetext{
* MS; ***PhD, Adjunct Professor - Discipline of Periodontics, School of Dentistry of Araraquara, São Paulo State University.

** Private practice.

*** PhD, Assistant Professor, Discipline of Periodontics, School of Dentistry of Lins, Piracicaba Methodist University.
} 
Leite FRM, Moreira CS, Theodoro LH, Sampaio JEC. Blood cell attachment to root surfaces treated with EDTA gel. Braz Oral Res 2005;19(2):88-92.

functional fibrous attachment can be formed with cementum and alveolar bone formation ${ }^{1}$. Nowadays, there is lack of information about the interaction between collagen fibers and clot, and also between clot and connective tissue.

Acid and chelating agents, such as citric acid and EDTA, respectively, can cause collagen fiber exposure and enhancement of connective tissue attachment to the root surface ${ }^{1}$. Also, the adsorption and adhesion of blood elements to denuded roots, during periodontal plastic surgeries, are important for the outcomes of wound healing ${ }^{2}$.

Fibrin linkage to collagen fibers and root thrombogenicity during the earliest step of the healing process are in part responsible for the rest of the events for tissue attachment ${ }^{2}$.

The aim of this study was to evaluate the influence of two different EDTA gels on blood element adsorption and adhesion to root surfaces.

\section{MATERIALS AND METHODS}

Before all procedures, the research ethics committee's approval and patients' permission were obtained. Ten human teeth were extracted and used in this experiment; all teeth were affected by periodontal disease, characterized by bleeding on gentle probing and absence of caries or restorations below the cemento-enamel junction. Extracted teeth were individually placed in capped tubes (Eppendorf, New England, USA) containing saline solution (Merck, Darmstadt, Germany).

\section{Sample preparation}

Two parallel grooves were made on the proximal root surfaces of each tooth using a high-speed cylindrical bur (KG Sorensen, Barueri, Brazil) under copious irrigation: the first one at the cemento-enamel junction and the other approximately $3 \mathrm{~mm}$ from it, in the apical direction.

The area between the two grooves was debrided and planed with 50 apical-cervical stroke movements using a Gracey 5-6 curette (Hu-Friedy, Chicago, IL, USA).

Thirty dentin blocks, approximately $3 \times 3 \times 1 \mathrm{~mm}$ in size, were obtained from roots using a diamond disk (KG Sorensen, Barueri, SP, Brazil) and stored in individual containers with saline solution to avoid dehydration.

Each of the three groups analyzed in this study contained 10 samples: 1) application of saline solution, 2) 24\% EDTA gel (Farmácia Santa Paula, Araraquara, São Paulo, Brazil) and 3) 24\%
EDTA gel (PrefGel, Biora AB, Malmö, Sweden). All substances were applied with a soft brush (Tigre, São Paulo, Brazil) for 3 minutes, changing solutions each 30 seconds, followed by $10 \mathrm{ml}$ saline solution wash. A healthy male volunteer was hematologically tested and a drop of his blood was placed on each dentin surface. Clot formation was allowed for 20 minutes in a humidified chamber ${ }^{1}$ (Plasvale, Gaspar, Brazil). The blocks were then rinsed 3 times for 5 minutes in PBS (Merck, Darmstadt, Germany). All steps were carried out at $36^{\circ} \mathrm{C}$ degrees (normal body temperature) and rinses were carried out in small Petri dishes (Corning, São Paulo, Brazil) with gentle swirling motion.

\section{SEM analysis preparation}

After the last 5-minute rinse, dentin blocks were fixed in 1\% formaldehyde (Merck, Darmstadt, Germany) in PBS for 15 minutes and rinsed three times for 5 minutes in PBS. Then, samples were incubated for 10 minutes in $0.02 \mathrm{M}$ glycine (Merck, Darmstadt, Germany) in PBS and rinsed again just like before. All dentin blocks were post-fixed in $2.5 \%$ glutaraldehyde (Merck, Darmstadt, Germany) in PBS for 30 minutes and rinsed as before. Specimens were dehydrated through a graded ethanol (Merck, Darmstadt, Germany) series: 25\%, $50 \%, 75 \%, 90 \%$ and 3 exchanges of $100 \%$. Then, the samples were dried overnight in a dehydration jar (Corning, São Paulo, Brazil), mounted on metallic stubs (Senai, São Paulo, Brazil) and sputter-coated with gold.

\section{SEM examination}

Three photomicrographs were obtained from a random area with $500 \mathrm{X}, 1,000 \mathrm{X}$ and 2,000 X magnifications, using a scanning electron microscope operated at an accelerating voltage of $20 \mathrm{kV}$ (Jeol T330 A, Jeol Ltd., Peabody, MA, USA). A previously calibrated and experienced examiner evaluated the images. In order to determine the degree of blood element adsorption and adhesion to the root surface, the following scores were used ${ }^{8,9,13}$ :

- Score 0: Absence of fibrin network and blood cells.

- Score 1: Scarce fibrin network and/or blood cells.

- Score 2: Moderate fibrin network and moderate quantity of blood cells.

- Score 3: Dense fibrin network and trapped blood cells. 
Leite FRM, Moreira CS, Theodoro LH, Sampaio JEC. Blood cell attachment to root surfaces treated with EDTA gel. Braz Oral Res 2005;19(2):88-92.

\section{Statistical analysis}

The scores were independently analyzed considering the substance used in each group (saline solution, manipulated EDTA - Santa Paula and industrialized EDTA - Biora gels). The non-parametric Kruskal-Wallis test was employed for average rank comparison among the groups. If $\mathrm{p} \leq 0.05$, Dunn's Multiple Comparison test was applied to detect statistically significant differences among the groups. Statistical analyses were performed by means of computer software (Graph Pad Instat Software 5.05, San Diego, CA, USA).

\section{RESULTS}

Control and manipulated EDTA groups showed a great variation in morphologic aspects of fibrin network and blood cell amount, as seen in Graph 1.

The null hypothesis was rejected by KruskalWallis test, denoting that not all groups had the same performance $(H=9.8336)$. The $p$ values obtained by mean post comparison showed no differences between control and Santa Paula's EDTA $(\mathrm{p}=0.2133)$ and, Santa Paula's and Biora's ${ }^{\circledR}$ EDTA $(p=0.0637)$. Differences were found between control and Biora's ${ }^{\circledR}$ EDTA ( $\left.p=0.0019\right)$. Table 1 summarizes Kruskal-Wallis test results; group mean posts (R) allow the ordination of groups. The best result in terms of fibrin clot organization with blood cell entrapment was obtained in the control group (Figures 1 and 2), in which only distilled water irrigation was carried out. Santa Paula's

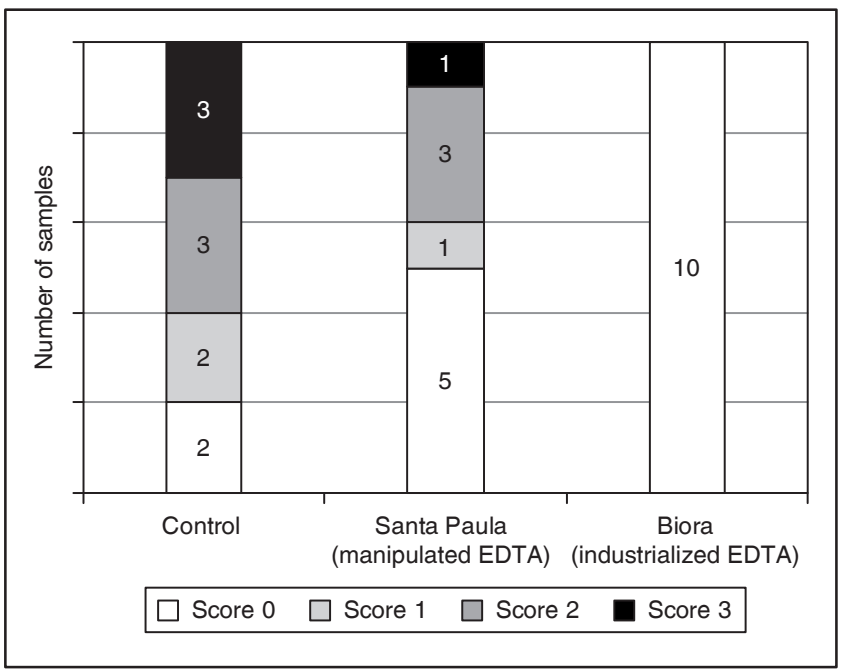

GRAPH 1 - Score distribution according to the different treatments performed.
EDTA showed a great variation of results in vitro, with a median score around 1 (Figures 3 and 4). Biora's ${ }^{\circledR}$ EDTA inhibited blood element adsorption and adhesion completely (Figures 5 and 6).

\section{DISCUSSION}

The main objective of periodontal therapy is to obtain new connective tissue attachment to roots previously exposed to oral environment or inside periodontal pockets ${ }^{7}$.

Nowadays, it is well known that fibrin network linkage to collagen fibers exposed at root surfaces is necessary for better outcomes after periodontal plastic surgery ${ }^{9,10}$. Some studies that analyzed the early events of clot formation on roots etched by citric acid suggested that surface thrombogenicity is important for the adsorption of blood components. In addition, they suggested that collagen fiber exposure by the use of an acid could improve clot organization, retard gingival epithelium downgrowth and enhance clinical attachment gain ${ }^{6,12}$.

Due to its neutral $\mathrm{pH}$ and chelating characteristic, in vitro studies employing EDTA showed that it is effective to remove smear layer and to expose collagen fibers properly ${ }^{3-5}$. According to the related literature, one of the most recommended substances for root biomodification is citric acid, but because it is an acid it usually necrotizes the surrounding periodontal tissues, fact that does not occur with EDTA, even when used excessively ${ }^{5}$.

In this study, the quantification of blood components adhered to the root surface after application of these substances was verified. Also, the differences in clot morphology were considered.

EDTA inhibited blood element adsorption and adhesion to dentin surface (Figures 3 to 6), result that may be attributed to a possible incomplete removal of the gel from the root surface. Also, EDTA is a calcium chelator ${ }^{5}$; therefore, its residues may have inhibited or retarded coagulation events.

According to Shuman ${ }^{11}$ (2000), collagen exposure favors two steps of the clot formation: the first one is the coagulation cascade activation, which

TABLE 1 - Sum of Kruskal-Wallis test values: experimental group mean posts and significant $\mathrm{p}$ values.

\begin{tabular}{c|c|c|c}
\hline \hline Groups & $\mathrm{N}$ & $\begin{array}{c}\mathrm{R} \\
(\mathrm{H}=9.8336)\end{array}$ & $\mathrm{p}<0.05$ values \\
\hline 1 & 10 & 21.2000 & $1 \& 3 \mathrm{p}=0.0019$ \\
\hline 2 & 10 & 16.3000 & - \\
\hline 3 & 10 & 9.0000 & - \\
\hline \hline
\end{tabular}


Leite FRM, Moreira CS, Theodoro LH, Sampaio JEC. Blood cell attachment to root surfaces treated with EDTA gel. Braz Oral Res $2005 ; 19(2): 88-92$.

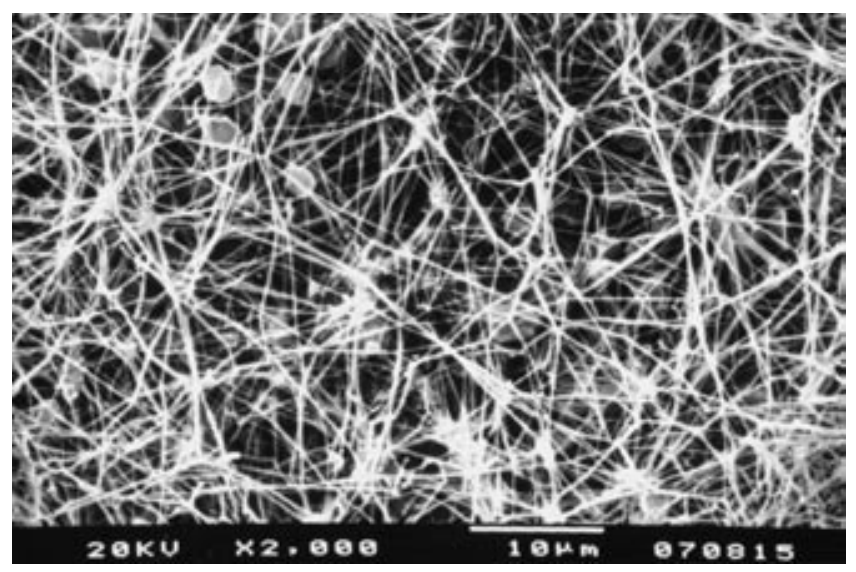

FIGURE 1 - Group 1 (control). Root surface covered by moderate fibrin network with moderate quantity of blood cells (score 2) (Bar $10 \mu \mathrm{m}$; Original magnification $2,000 \mathrm{X})$

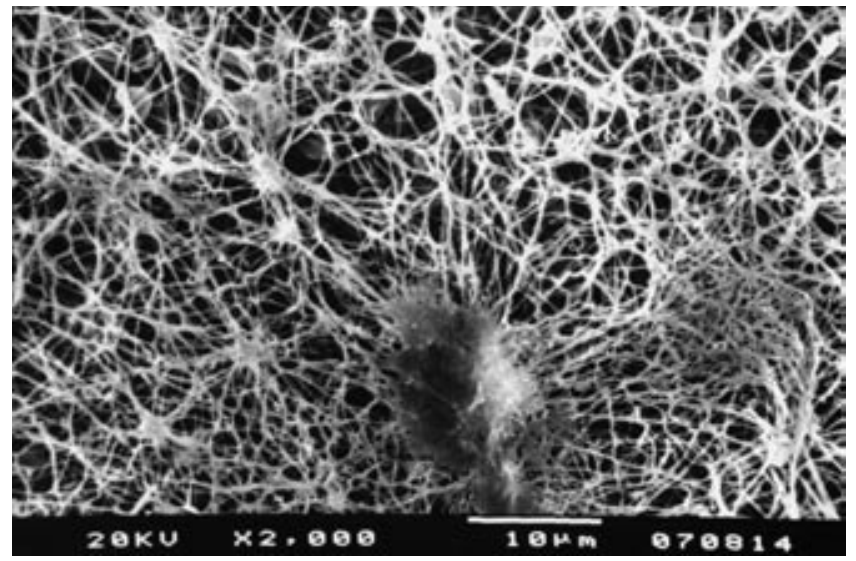

FIGURE 2 - Group 1. Organized fibrin network with a few entrapped blood cells (score 2) (Bar $10 \mu \mathrm{m}$; Original magnification 2,000 X).

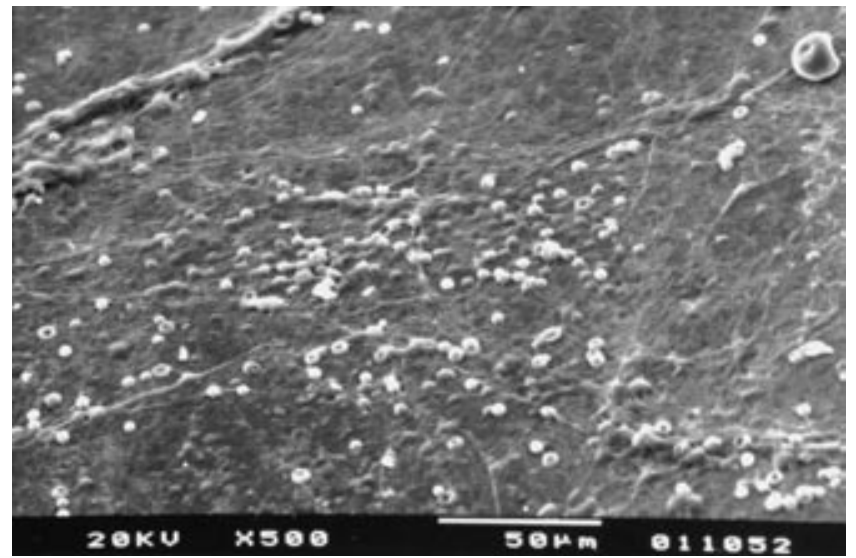

FIGURE 3 - Group 2 (Santa Paula's EDTA). Scarce cells covering the conditioned root surface (score 1) (Bar $50 \mu \mathrm{m}$; Original magnification $500 \mathrm{X})$.

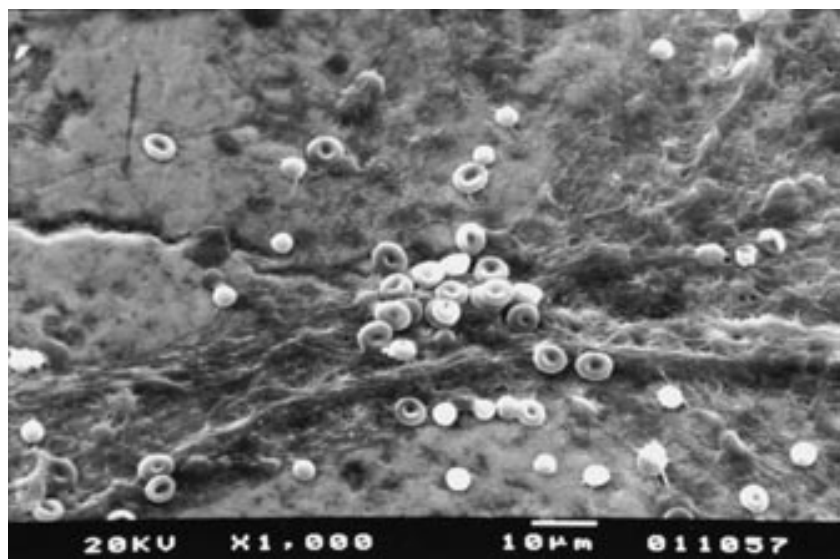

FIGURE 4 - Group 2. Poorly organized fibrin network with few adhered blood cells (score 1) (Bar $10 \mu \mathrm{m}$; Original magnification $1,000 \mathrm{X}$ ).

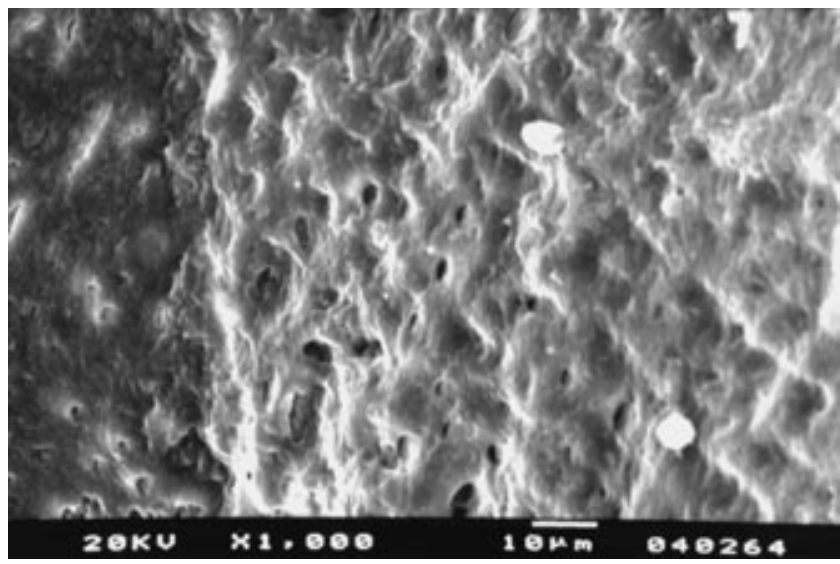

FIGURE 5 - Group 3 (Biora's EDTA). Complete inhibition of fibrin network formation. Surface without smear layer coverage (Bar $10 \mu \mathrm{m}$; Original magnification $1,000 \mathrm{X})$.

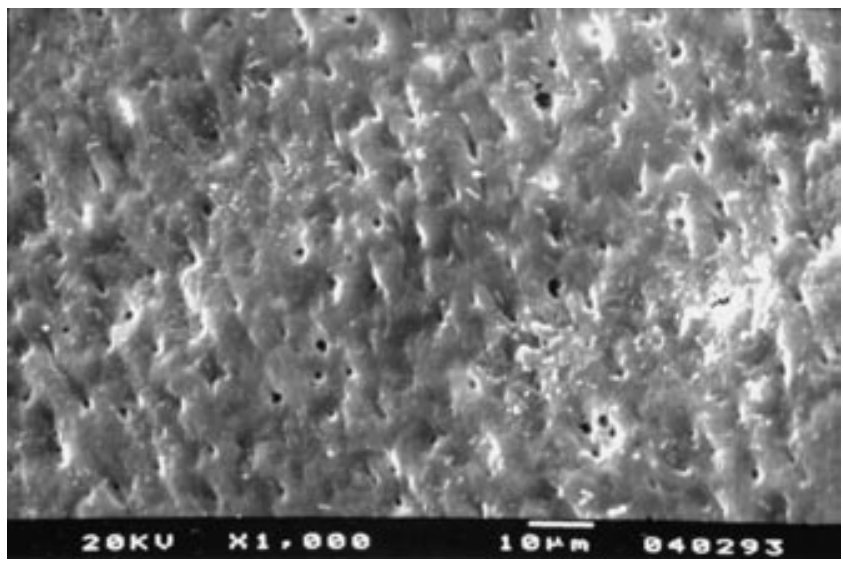

FIGURE 6 - Group 3. Root surface showing absence of blood components. Dentinal tubule opening can be observed, denoting smear layer removal (Bar $10 \mu \mathrm{m}$; Original magnification 1,000 X). 
Leite FRM, Moreira CS, Theodoro LH, Sampaio JEC. Blood cell attachment to root surfaces treated with EDTA gel. Braz Oral Res 2005;19(2):88-92.

originates the fibrin network. The second step is the induction of platelet adhesion, aggregation, activation followed by degranulation of its cytoplasm granules, resulting in thrombus formation.

Due to the methodology applied in this study and its limitations, the viability of blood cells that adhered to the root surface and clot thickness could not be evaluated.

The healing process is very complex, especially during clot initial formation, granulation tissue organization and collagen fiber deposition. Since some studies have shown not so good clinical results with EDTA, in vivo experiments should be carried out to evaluate whether the conditions of clot formation, after the use of this substance, are favorable or not.

The differences observed between the two EDTA gels can probably be attributed to the number of chelation sites present in each one of their molecules. Industrialized EDTA contains disodium, while the manipulated one contains trisodium. Thus, each molecule of Santa Paula's EDTA is capable of removing three calcium molecules from root surfaces, and Biora's EDTA, two.

\section{REFERENCES}

1. Baker PJ, Rotch HA, Trombelli L, Wikesjö UME. An in vitro screening model to evaluate root conditioning protocols for periodontal regenerative procedures. J Periodontol 2000;71:1139-43.

2. Bal B, Eren K, Balos K. Effects of various root surface treatments on initial clot formation: a scanning electron microscope study. J Nihon Univ School Dent 1990;32:281-93.

3. Bergenholtz A, Babay N. Scanning electron microscopy of the root surface texture of extracted periodontally diseased teeth following various etching and chelating regimens. Int J Periodontics Restorative Dent 1998;18(2):171-9.

4. Blomlöf L, Bergman E, Forsgardh A, Foss L, Larsson A, Sjoberg B. A clinical study of root surface conditioning with an EDTA gel. I. Non surgical periodontal treatment. Int J Periodontics Restorative Dent 1998;20:561-5.

5. Blomlöf J, Blomlöf L, Lindskog S. Effect of different concentrations of EDTA on smear layer removal and collagen exposure in periodontitis-affected root surfaces. J Clin Periodontol 1997;24:534-7.

6. Larjava H, Salomen J, Hakkinem L, Narhi T. Effect of citric acid treatment on the migration of epithelium on root surfaces in vitro. J Periodontol 1988;1:95-9.

7. Leite FRM, Moreira CS, Theodoro LH, Sampaio JEC. Blood cell adhesion on chemically conditioned root surfaces [abstract]. Braz Oral Res 2004;18 Suppl:21.
It can be suggested that manipulated EDTA removes superficial calcium molecules from the tooth surface and loses affinity to the surface. The industrialized EDTA remains attached to the root, probably because the amount of remaining calcium ions is higher, attracting EDTA molecules, making its complete removal harder.

\section{CONCLUSIONS}

According to the results obtained and within the limitations of this methodology, it can be inferred that:

1. The use of EDTA gel in root biomodification can inhibit clot formation and stabilization on root surface.

2. Root debridement and planing is capable of providing a surface where adsorption and adhesion of blood components is stable.

\section{ACKNOWLEDGMENT}

This study was supported by grant number 03/04252-2 and 03/04754-8 from FAPESP (The State of São Paulo Research Foundation).

8. Moreira CS, Zandim DL, Leite FRM, Theodoro LH, Sampaio JEC. Efeito do condicionamento radicular com EDTA, ácido cítrico e tetraciclina na adesão de células sangüineas [abstract]. Braz Oral Res 2004;18 Suppl:87.

9. Polson AM, Frederick GT, Ladenheim S, Hanes PJ. The production of a root surface smear layer by instrumentation and its removal by citric acid. J Periodontol 1984;55:443-6.

10. Polson AM, Proye MP. Fibrin linkage: a precursor for new attachment. J Periodontol 1983;54:141-7.

11. Shuman M. Hemorrhagic disorders: abnormalities of platelet and vascular function. In: Goldman L, Bennett JC. Cecil textbook of medicine. $21^{\text {st }}$ ed. Philadelphia: Saunders; 2000. p. 23.

12. Steinberg AD, Willey R. Scanning electron microscopy observations of initial clot formation on treated root surfaces. J Periodontol 1988;59:403.

13. Theodoro LH. Ação do laser de Er:Yag e de diodo na adesão de elementos sanguíneos e na morfologia de superfície radicular irradiadas. Estudo através de microscopia eletrônica de varredura [Tese de Doutorado]. Araraquara: Faculdade de Odontologia da UNESP; 2003.

14. Trombelli L, Scabbia A, Zangari F, Griselli A, Wikesjö UME, Calura G. Effect of tetracycline $\mathrm{HCl}$ on periodontally-affected human root surfaces. J Periodontol 1995;66(8):685-91. 